\title{
2.2. Od pomysłu do realizacji. Retoryczna analiza telewizyjnego filmu dokumentalnego Michała Fajbusiewicza i Waldemara Piaseckiego pt. Moja Misja - Krzysztof Grzegorzewski \\ https://doi.org/10.18778/8220-429-2.05
}

\subsubsection{Wstęp}

W przedstawionym Czytelnikowi tekście proponuję analizę jednego z mało już znanych i dotąd nieopracowanych telewizyjnych filmów dokumentalnych z bardzo bogatego dorobku łódzkiego dziennikarza, reportażysty i dokumentalisty telewizyjnego, Michała M. Fajbusiewicza. Dorobek ten, szacowany na blisko 200 publikacji (nie licząc programów cyklicznych, jak np. 997, Stan Krytyczny, Dajcie znakżycia, Z Dwójką dookoła świata, inne), zawiera bardzo różnorodne tematycznie reportaże i filmy dokumentalne, produkowane zarówno na potrzeby anten ogólnopolskich TVP, jak również łódzkiej anteny lokalnej. Znajdują się tam reportaże poświęcone sprawom społecznym, kryminalnym, ale także historycznym, podróżniczym, kulturalnym, a nawet - jak dziś by je określono - lifestyle'owym.

Osobną, bardzo ciekawą częścią tej twórczości jest seria filmów o tematyce żydowskiej. Niewątpliwie przyczynkiem do ich powstania był film do dziś uważany za najważniejszy w dorobku tego twórcy: Moja Misja, w całości poświęcony postaci prof. Jana Karskiego i jego roli w historii Polski XX wieku. Film ten - będący z formalno-prawnego punktu widzenia filmem dokumentalnym ${ }^{8}$ - był jedynym, jaki nakręcono i wyemitowano w Polsce jeszcze za życia profesora i z jego udziałem. Emisja filmu przyczyniła się de facto do ponownego odkrycia w Polsce postaci Jana Karskiego i uświadomienia polskiej opinii publicznej doniosłości jego misji. Taki był też cel przedsięwzięcia Michała Fajbusiewicza i Waldemara Piaseckiego.

Pomysł na film był przypadkowy: wiązał się z przygotowywaniem się M. Fajbusiewicza do wyjazdu do USA, gdzie na zlecenie Niny Terentiew miał zrealizować reportaże o policji nowojorskiej ${ }^{9}$. W ramach tych przygotowań dziennikarz rozmawiał jesienią 1995 roku z Waldemarem Piaseckim - emigrantem, osobistym sekretarzem prof. Jana Karskiego ${ }^{10}$ - który zainteresował go postacią profe-

8 B. Fiołek-Lubczyńska definiuje reportaż artystyczny jako jeden z rodzajów filmu dokumentalnego, wywodzącego się z gatunków filmowych (por. rozdział 3.1) i takie określenie można również zastosować do filmu Moja Misja z punktu widzenia genologii dziennikarskiej. Niemniej w sensie formalno-prawnym produkcja ta została zakwalifikowana jako film dokumentalny, co wiązało się także z innym budżetowaniem oraz o wiele wyższymi wynagrodzeniami dla autorów (rozmowy z M. Fajbusiewiczem z 15 marca 2020; nagrania i korespondencje w archiwum autora).

9 Chodzi o dwuczęściowy reportaż Policja nowojorska, wyemitowany w 1996 roku na antenie TVP 2 jako wydanie specjalne magazynu 997.

10 Z Waldemarem Piaseckim skontaktował Michała Fajbusiewicza operator TVP Łódź, Adam Kaczanowski. 
sora i namówił do stworzenia filmu na jego temat. Początkowo trudności sprawiał research dziennikarski: w Polsce niewiele było dotąd publikacji poświęconych Janowi Karskiemu. Potwierdzało to tezę W. Piaseckiego, że prof. Karskiego nie doceniano w kraju. W tej sytuacji pozostawała kwerenda artykułów prasowych. Decyzją Andrzeja Fidyka, wówczas szefa reportażu w TVP1, Michał Fajbusiewicz został wysłany do USA, by przeprowadzić pierwsze wywiady z prof. Karskim $^{11}$. Budżet przyznany przez A. Fidyka systematycznie się powiększał, ponieważ M. Fajbusiewicz z J. Karskim i ekipą TVP Łódź jeździł po kilku krajach świata, rejestrując zdjęcia. Jak przyznał: „To była moja największa i najdroższa produkcja w życiu" (Fajbusiewicz, Omilianowicz 2019: 234).

Trwający 74 minuty film o Janie Karskim - bardzo długi jak na standardy telewizyjnych filmów dokumentalnych - zaowocowal jeszcze kilkoma innymi produkcjami o nim, jakie mogli oglądać widzowie TVP1, ale także lokalnego programu TVP3 Łódź. Są to m.in.: Profesor Jan Karski, Profesor Jan Karski w Łodzi, Debata Karski-Giedroyć ${ }^{12}$, a także relacje $z$ wręczenia J. Karskiemu doktoratu honoris causa Uniwersytetu Łódzkiego (rok 1996) oraz tytułu Honorowego Obywatela Miasta Łodzi (rok 2000 - wraz z M. Edelmanem, R. Polańskim i K. Dejmkiem). Jakkolwiek M. Fajbusiewicz interesował się już wcześniej tematyką żydowską (por. film Kenda Bar Gera z 1994 roku), to Moja Misja niewątpliwie była inspiracją dla innych jego filmów tej tematyce poświęconych. Zaliczamy do nich m.in.: Dr Ores, Kiedyś Hersz - dziś Grzegorz, Człowiek, którego nie byto na liście Schindlera, Spowiedź, Oficer Legii Honorowej, inne). Ten fakt również przesądza o wadze filmu Moja Misja. Proponowana poniżej analiza jest w istocie początkiem badań nad dorobkiem reporterskim i dokumentalnym Michała Fajbusiewicza, który dotąd nie doczekał się medioznawczego opracowania.

\subsubsection{Materiał badawczy i metoda badań}

Podstawową dla niniejszej analizy jednostką materiałową jest film dokumentalny Moja Misja według scenariusza i w reżyserii Michała Fajbusiewicza i Waldemara Piaseckiego ${ }^{13}$. M. Piasecki odpowiadał za organizację wyjazdów, kontakty

${ }^{11}$ Wszystkie informacje pochodzą z osobistych rozmów z M. Fajbusiewiczem (nagrania $w$ archiwum autora analizy) oraz wywiadu-rzeki z tym dziennikarzem. Por. Fajbusiewicz, Omilianowicz 2019: 230-249.

${ }_{12}$ Michał Fajbusiewicz i Adam Kaczanowski zarejestrowali pierwsze - bodaj jedyne - spotkanie Jana Karskiego z Jerzym Giedroyciem w Maisons-Laffitte pod Paryżem. $Z$ trwającego 3 godziny nagrania zaproponowano widzom godzinny skrót rozmowy, który wyemitowano w 1996 roku.

${ }^{13}$ Udział Waldemara Piaseckiego w scenariuszu i reżyserii filmu był warunkiem postawionym przez prof. Karskiego. Wszystkie informacje nt. jego udziału w produkcji filmu pochodzą z rozmowy autora analizy z red. Fajbusiewiczem z 15 i 16 marca $2020 \mathrm{r}$. (nagranie w archiwum autora). 
międzynarodowe z licznymi osobami i instytucjami, służył wiedzą merytoryczną oraz wszelką pomocą organizacyjną. Dzięki niemu możliwe było zarejestrowanie wywiadów z szeregiem osobistości i przedstawicieli instytucji państwowych, publicznych i naukowych w kilku krajach, m.in. w USA i Izraelu. M. Fajbusiewicz odpowiadał za kwerendę, układ materiału w filmie, współpracę z operatorem Adamem Kaczanowskim, wykorzystanie zdjęć i materiałów archiwalnych, prowadzenie wywiadu dziennikarskiego (niekiedy jednak przy pomocy W. Piaseckiego), słowem: wszelkie prace dziennikarskie i koncepcyjne dziennikarza telewizyjnego. W tym sensie efekt końcowy - gatunek dziennikarski, który powstał - jest przede wszystkim jego dziełem.

Materiał pomocniczy do analizy stanowi dokumentacja, w tym stenogramy w postaci elektronicznej przygotowane przez asystentkę red. Fajbusiewicza, Joannę Przybył; zawierają one dosłowny opis nagrań roboczych ze wszystkich kaset (w tym zapisy wszystkich rozmów). Pierwotnie zarejestrowano czterdzieści dwie 30-minutowe kasety systemu Betacam SP, z których do chwili publikacji niniejszego tekstu zachowało się jedynie dziesięć, z nagraniami wykorzystanymi w filmie oraz nigdzie niepublikowanymi materiałami z czasu ostatniego pobytu Jana Karskiego w Łodzi w 2000 roku (na miesiąc przed śmiercią). Zawartość tych kaset jest cennym uzupełnieniem analitycznego spojrzenia na film, jest tam bowiem wiele cennej wiedzy pochodzącej od samego profesora jako świadka historii XX wieku.

Nad filmem pracowała $\mathrm{z}$ red. Fajbusiewiczem ta sama ekipa, która uczestniczyła w niemal wszystkich jego produkcjach reporterskich i dokumentalnych oraz - z niewielkimi zmianami w ciągu powstawania - wielu produkcjach seryjnych, przede wszystkim przy magazynie 997 . Stąd też widzowie mogą się doszukiwać wielu podobieństw stylistycznych w zakresie formy tych programów. W jej składzie warto wyróżnić wysoko cenionego operatora Adama Kaczanowskiego.

Jako autor analizy pragnę złożyć serdeczne podziękowania red. Michałowi Fajbusiewiczowi za udostępnienie tych unikalnych materiałów i bogatej dokumentacji.

Celem prezentowanego tekstu jest dokonanie retorycznej analizy filmu Moja Misja przy użyciu dwóch metod retorycznej analizy tekstu: neoklasycznej i gatunkowej. Efektem analizy ma być odpowiedź na pytania:

1. W jaki sposób został skomponowany ten film dokumentalny i wykonania jakiej pracy wymagał od twórców?

2. Czy badany film spełnia założenia gatunkowe telewizyjnego filmu dokumentalnego? (Godzic, Kozieł, Szydło-Kwas 2015; Godzic 2004; Uszyński 2004).

Jak zaznacza B. Fiołek-Lubczyńska (por. rozdział 3.1), kluczowe z punktu widzenia takich badań jest traktowanie filmu dokumentalnego jako tekstu kultury. Rodzi to następujące konsekwencje:

- jest on ograniczony,

- stanowi całościowy komunikat w strumieniu telewizyjnym, 
- przedstawia określoną wartość formalną i tematyczną,

- zawiera pogłębioną, autorską refleksję.

Jak zauważa Mirosław Przylipiak, retoryczność filmu dokumentalnego jako tekstu kultury „nie polegałaby po prostu na uporządkowaniu, na jakiejś kompozycji, lecz na organizacji dyskursywnej przekazu" (Przylipiak 2004: 104). Dokonując retorycznej analizy dokumentu, należy więc zbadać następujące elementy:

- kompozycję rozumianą jako sposób organizacji materiału faktograficznego w celu skutecznej argumentacji (inventio, dispositio),

- jakość tekstu werbalnego jako nadrzędnego w stosunku do przekazu audialnego i wizualnego,

- jakość przekazu audialnego i wizualnego jako składników współkomponujących sens i sprzyjających perswazji.

Badania zostały przeprowadzone $\mathrm{z}$ użyciem wybranych retorycznych metod analizy tekstów (Foss 2004). Wśród metod tych - wskazanych przez J.Z. Lichańskiego jako dających się wykorzystać do badań medialnych (Lichański 2010: 387-388) - zdecydowano się na wybór:

a) krytyki neoklasycznej - wywodzącej się z retoryki arystotelejskiej, kwintyliańskiej, cycerońskiej i innych klasyków, a skoncentrowanej przede wszystkim na etapach przygotowania i kompozycji tekstu;

b) analizy gatunkowej - traktującej badany tekst jako reprezentanta określonego gatunku, tu: gatunku dziennikarskiego, jakim jest telewizyjny film dokumentalny.

Wybór dwóch z jedenastu w sumie dostępnych metod analizy tekstu jest na potrzeby krótkiej analizy wystarczający - ale podyktowany także pewnymi ograniczeniami. $Z$ perspektywy retoryczności reportażu artystycznego (i szerzej: filmu dokumentalnego) proponowanej $\mathrm{w}$ tym tomie kluczowe znaczenie ma analiza jego kompozycji: traktowanie audiowizualnego tekstu kultury tak samo, jak tekstu werbalnego: przemowy, którą należy skomponować tak, by byla przekonująca.

Oczywiście do bardziej szczegółowych i wyspecjalizowanych badań nadają się także inne uporządkowane przez J. Lichańskiego metody retoryczne. Analizując Moją Misję, można rozważyć jeszcze podejście dramatystyczne - postrzegające tekst jako „ucieleśnienie swoistego dramatu, na który składają się takie elementy jak: kto zrobił, co zrobil, gdzie, jak, kiedy, za pomocą czego i z czyją asystą" (Lichański 2010: 388). Byłoby ono zasadne o tyle, że można za jego pomocą przyjrzeć się postaci głównego bohatera tekstu, Jana Karskiego, a raczej sposobowi, w jaki została ta postać ukazana w dokumencie pod względem merytorycznym. Analiza taka nie dotyczyłaby jednak dokumentu telewizyjnego jako takiego, który jest w tym opracowaniu najważniejszy. Wymaga ona poza tym poszerzonej wiedzy z publikacji na temat II wojny światowej i Holocaustu (Rees 2018), znajomości historii Polski (Sowa 2011; Wieczorkiewicz 2014) i świata w XX wieku (Bankowicz 2004), a przede wszystkim w czasach współczesnych 
profesorowi Karskiemu i jego działalności. Film koncentruje się w dużej mierze na jego misjach kurierskich, w tym najważniejszej: poinformowaniu polityków świata zachodniego (krajów alianckich) o tragedii Żydów na ziemiach polskich. Jednak nie tylko - można go w szerokiej perspektywie potraktować także jako film biograficzny, prezentuje on bowiem w skrócie całe życie profesora, od jego łódzkiego dzieciństwa, przez doświadczenia wojenne oraz pracę i życie na emigracji w USA, w tym karierę zawodową, po sukcesy i osiągnięcia, a nawet osobiste wątki biograficzne (np. związek małżeński z Polą Nireński). Analiza taka byłaby ciekawa jako prezentująca „świat przedstawiony” tego filmu i z pewnością zasługuje na osobne opracowanie.

Podobnie przedstawia się przeprowadzenie analizy metaforycznej (skoncentrowanej na badaniu aparatu tropologicznego). Byłoby ono również możliwe, choć w jakimś osobnym tekście badawczym. Można by je rozszerzyć jeszcze o elementy analizy narracyjnej (korzystającej z narzędzi narratologicznych) i wreszcie neoretorycznej (śledzącej aparat argumentacyjny tekstu, przesądzający o jego racjonalności). Analiza taka byłaby dwupłaszczyznowa:

a) język, styl i argumentacja wypowiedzi bohatera filmu, prof. Jana Karskiego, wraz z wypowiadającymi się na jego temat innymi osobami w filmie jako kontekście;

b) język, styl i argumentacja autorów, tu: M. Fajbusiewicza i W. Piaseckiego, manifestujące się na poziomie werbalnym w postaci tekstu lektorskiego odczytywanego przez T. Boruszczaka.

Można tu bowiem mówić o dwóch homo rhetoricusach (Grzegorzewski 2014) występujących w filmie: J. Karskim oraz, w szerszym sensie, M. Fajbusiewiczu i W. Piaseckim (retoryczny podmiot zbiorowy). Badania przekazu werbalnego byłyby skoncentrowane w pierwszym przypadku na indywidualnej retoryce mówcy w odniesieniu do pojęcia podmiotu retorycznego (Grzegorzewski 2014: 25-43), zaś w drugim: retoryce specyficznie zredagowanego tekstu dziennikarskiego (Pisarek 2002) i ew. jego wykonania lektorskiego z perspektywy prozodii komunikacyjnej (Szwajkowska 2013). W odniesieniu do samego filmu, a więc działań Michała Fajbusiewicza jako twórcy, można przeprowadzić także badania nad przekazem pozawerbalnym, przy użyciu narzędzi wypracowanych przez filmoznawców pracujących nad filmem dokumentalnym i reportażem (Przylipiak 2006; Skarżyńska 2011). W tekście niniejszym, w odniesieniu do Mojej misji, problematyka ,ja mówiącego" zostaje przywołana jedynie jako cecha kompozycyjna tego filmu.

Metod i sposobów analizowania jest zatem dużo, jednak celem tej analizy pozostaje kompozycja. Według zasad klasycznej retoryki kwintyliańskiej wyróżniamy pięć etapów przygotowania tekstu: inventio (zbieranie materiałów i informacji), dispositio (opracowanie materiałów i sposobu ich wykorzystania), elocutio (nadanie odpowiedniej formy stylistycznej), memoria (zapamiętanie mowy), actio (wygłoszenie) (Kwintylian 2002). Przykładając ten schemat do telewizyjnego filmu dokumentalnego, można stwierdzić, że: 
a) inventio należy rozumieć jako zbieranie materiału do publikacji w postaci szeroko i wąsko rozumianego wywiadu dziennikarskiego (Adams, Hicks 2007), dokonanie kwerendy (także w odnośnych archiwach) oraz wykonanie zdjęć filmowych;

b) dispositio obejmuje wszelkie działania polegające na opracowywaniu zebranego materiału, a więc selekcję i segregację materiałów (gatekeeping), ustalenie ich kolejności oraz kontekstu występowania w filmie;

c) elocutio oznacza wszystkie zabiegi mające na celu stworzenie określonego gatunku telewizyjnego: edycję i montaż zdjęć, udźwiękowienie, oprawę muzyczną, napisanie ewentualnego tekstu lektorskiego i zlecenie przeczytania go wybranemu lektorowi, napisy i infografiki, wreszcie audiowizualne efekty specjalne;

d) memoria w przypadku gatunku telewizyjnego sprowadza się do zapisania gotowej formy w postaci analogowej lub cyfrowej, na nośniku fizycznym bądź wirtualnie w postaci pliku;

e) actio w przypadku telewizji oznacza wyemitowanie programu na antenie premierowo i później w postaci powtórzeń, a obecnie także udostępnienie online i wreszcie wydanie z przeznaczeniem na rynek (samą emisję można jeszcze uzupełnić o zapowiedź lub/i dyskusję, a wydanie komercyjne o jakieś materiały dodatkowe) ${ }^{14}$.

O formie utrwalenia oraz emisji filmu dokumentalnego decyduje nie autor, lecz odnośna redakcja telewizyjna, przeto analiza przeprowadzona została na trzech plaszczyznach: inventio, dispositio, elocutio.

\subsubsection{Retoryczna analiza filmu Moja Misja}

\subsubsection{Inventio - zbieranie materiałów do publikacji}

Przystępując do analizy, należy wskazać cel, jakim autor się kierował, zrekonstruować etapy powstawania filmu oraz - w miarę możliwości - ustalić, jakie były materiały wyjściowe do jego produkcji. Jak już wspomniano wcześniej, pomysł stworzenia Mojej Misji był de facto przypadkowy. Po rozmowie z W. Piaseckim Michał Fajbusiewicz bardzo szybko zafascynował się postacią prof. Karskiego i postanowił przekonać do realizacji i emisji filmu Andrzeja Fidyka. Celem, jaki sobie dziennikarz postawił, było „odkrycie” na nowo polskim telewidzom postaci Jana Karskiego oraz uświadomienie doniosłości jego misji kurierskiej w historii II wojny światowej i historii Polski.

Publikacji książkowych czy monografii na temat Jana Karskiego w Polsce wówczas nie było; okazało się także, że niewiele było publikacji samego profesora

${ }^{14} \mathrm{~W}$ przypadku niniejszego filmu na actio składa się jeszcze przygotowanie płyty DVD z filmem, prezentacje filmu przez autora na licznych spotkaniach w Polsce i zagranicą (m.in. w środowiskach polonijnych i żydowskich w USA), wreszcie przygotowanie multimedialnej płyty pt. Jan Karski. Powrót bohatera, wydanej przez Muzeum Miasta Łodzi i szereg prelekcji dla młodzieży na podstawie tej płyty. 
(tę najważniejszą, The story of the secret state, wydano w Polsce w 1999 roku w thumaczeniu W. Piaseckiego, potem w roku 2014 w tłumaczeniu Grzegorza Siwka - por. Karski 2014). Autor filmu zaczynał od artykułów prasowych oraz rozmowy z samym J. Karskim w Warszawie w 1995 roku, gdzie profesor przebywał na zaproszenie ówczesnego prezydenta RP Aleksandra Kwaśniewskiego. Zgoda szefa redakcji reportażu TVP1 i przyznany budżet umożliwiły w 1996 roku wyjazd ekipy TVP Łódź do USA, gdzie można było zacząć realizację. Jak przyznaje sam M. Fajbusiewicz, nie istniał początkowo żaden przygotowany plan działania ani tym bardziej produkcji. Zaczęto od rozmów z samym profesorem, a następnie rejestrowano wywiady niemal ze wszystkimi związanymi z nim osobami, do jakich w ogóle udało się dotrzeć. Prace te miały charakter improwizowany, w dużej mierze spontaniczny (co skądinąd jest charakterystyczne dla zawodu dziennikarskiego i Michał Fajbusiewicz także wielokrotnie tak działał ${ }^{15}$ ) - tym samym mają w sobie więcej ze specyfiki pracy reportera niż producenta czy reżysera filmowego. $\mathrm{W}$ zakresie inventio opierają się one na szeroko i wąsko rozumianym wywiadzie dziennikarskim: pozyskiwania informacji na potrzeby publikacji oraz wielu wywiadów z osobami związanymi z profesorem. Bardzo wiele merytorycznego wkładu oraz organizacyjnej pomocy zapewnił Waldemar Piasecki, osobisty sekretarz J. Karskiego: dzięki niemu m.in. było możliwe dotarcie do wielu osobistości Izraela oraz rozmowy w przedstawicielami środowisk żydowskich w Ameryce. W. Piasecki jest także specjalistą znającym znakomicie życiorys Jana Karskiego; opublikował dwie części poświęconej mu niezwykle obszernej biografii (Piasecki 2015, 2017; trzecia część w przygotowaniu). Dysponował więc naonczas niezliczoną ilością informacji i szczegółów, a także wieloma znajomościami, które - poza otwartością samego profesora - $\mathrm{w}$ dużej mierze ukształtowały film pod względem merytorycznym. Autorzy Mojej misji zadbali o pozyskanie wielu cennych źródeł informacji w postaci wywiadów dziennikarskich, m.in. z polskimi i zagranicznymi politykami (np. Aleksander Kwaśniewski, Meir Lau, Szewach Weiss), uznanymi przedstawicielami świata kultury i mediów (m.in. Jerzy Giedroyc, Ryszard Horowitz, Thomas Wood) czy wreszcie naukowcami (m.in. Jan Słowikowski, Józef A. Gierowski). W filmie pojawiają się wypowiedzi świadków historii, przede wszystkim osób, które zetknęły się z Janem Karskim, jak np. Żydzi ocaleni z getta warszawskiego. Najważniejszym jednak rozmówcą i źródłem bezcennej wręcz wiedzy historycznej był sam bohater filmu, prof. Jan Karski. Aby móc zrealizować film, Michał Fajbusiewicz i jego ekipa podróżowali z nim i rejestrowali zdjęcia w licznych miejscach w rodzinnej Łodzi, ale także w Warszawie i na terenie dawnego hitlerowskiego obozu koncentracyjnego w Izbicy. Wiele zdjęć nakręcono

15 Informacje pochodzą ze wspomnianego wcześniej wywiadu-rzeki (Fajbusiewicz, Omilianowicz 2019) oraz licznych rozmów przeprowadzonych przez autora artykułu z red. Fajbusiewiczem. 
w USA, gdzie profesor Karski żył i pracował po wojnie, oraz w Izraelu (wymienić tu należy choćby Bazylikę Narodzenia Pańskiego i Dolinę Zabitych Wspólnot).

Zachowane $\mathrm{w}$ archiwum autora kasety z materiałem roboczym zawierają dość obszerne fragmenty rejestracji z poszczególnych miejsc (np. 36 minut w Jerozolimie, podobnie w Betlejem itp.). Jak można przypuszczać, zawierają one także materiały nagrywane niejako „przy okazji”, wykorzystywane potem w innych, bieżących produkcjach - jak choćby zapis pasterki w bazylice w Betlejem czy życzenia dla wiernych składane z okazji Bożego Narodzenia i Nowego Roku przez polskiego księdza pełniącego tam posługę duszpasterską. M. Fajbusiewicz stwierdza, że w przybliżeniu zarejestrowano łącznie około 1500 minut materiału surowego ${ }^{16}$. W dokumentacji przygotowanej przez Joannę Przybył znajdują się opisy czterdziestu dwóch 30-minutowych kaset systemu Betacam SP, opatrzonych numerami katalogowymi archiwum TVP Łódź17, z samym tylko materiałem dziennikarskim.

Podstawą inventio był jednak nie tylko rezultat blisko rocznej pracy dziennikarskiej Michała Fajbusiewicza i Waldemara Piaseckiego. Przy realizacji filmu korzystano z archiwaliów TVP, archiwaliów Jana Karskiego, fragmentów wcześniejszych filmów i narracji o profesorze, archiwów Muzeum Holocaustu w Waszyngtonie, a także Kibucu im. Bohaterów Gett. Korzystano z pomocy PLL Lot, ambasad RP w Paryżu i Waszyngtonie. W przedsięwzięciu pomagali także Michał Hochman i Tadeusz Mysłowski. Na inventio składała się również wiedza pozyskana z innych przekazów dziennikarskich oraz wiedza samego Waldemara Piaseckiego jako pomysłodawcy filmu. Korzystano $\mathrm{z}$ archiwalnych materiałów fotograficznych i filmowych, wykonywanych m.in. na terenie getta łódzkiego i getta warszawskiego, obozów koncentracyjnych, okupowanej Polski oraz innych krajów związanych $\mathrm{z}$ akcją filmu. Chcąc przybliżyć telewidzom biografię profesora, wykorzystano zdjęcia przedwojennej Łodzi, na poziomie dispositio łączonymi z zapisem podróży Jana Karskiego z ekipą telewizyjną po swoim rodzinnym mieście i jego wspomnieniami (przeznaczono na to dwie kasety Betacam SP). Wspomnienia profesora ilustrowano zdjęciami związanych z nim pamiątek ${ }^{18}$.

16 Ponieważ na czterdziestu dwóch kasetach o długości 30 minut da się zapisać łącznie 1260 minut materiału, należy zakładać, że w liczbie podanej przez M. Fajbusiewicza zawierają się także nagrania realizowane z udziałem prof. Karskiego w 2000 roku. Miały one służyć do produkcji kolejnych filmów o profesorze.

1730 minut to maksymalny podawany przez producentów czas zapisu kasety Betacam SP w rozmiarze kamerowym (w praktyce można było dokonać niemal 35-36 minut nagrania). Kasety w większym rozmiarze - do magnetowidów studyjnych - oferowały maksymalnie ponad 90 minut zapisu. Magnetowid systemu Betacam SP w posiadaniu autora tekstu.

18 Wiele takich pamiątek zgromadzono w pałacu Poznańskich w Łodzi, gdzie z inicjatywy Michała Fajbusiewicza powstał specjalny gabinet profesora. Wskutek starań M. Fajbusiewicza nadano także imię Jana Karskiego jednej z ulic w centrum Łodzi, położonej w pobliżu pałacu Poznańskich i Manufaktury. 
$\mathrm{W}$ zakresie inventio film przygotowano więc nader skrupulatnie, a zebrana dokumentacja - tak w postaci nagrań wideo, jak również dokumentów pisanych, fotografii i materiałów archiwalnych - była niezwykle obszerna. Przybliżone obliczenia wskazują, że na czterdziestu dwóch kasetach można było zarejestrować 1260 minut materiału - a więc siedemnastokrotnie więcej niż czas trwania filmu. Ze względu jednak na wykorzystanie różnego rodzaju archiwaliów proporcje te powiększają się prawie półtorakrotnie ${ }^{19}$.

\subsubsection{Dispositio - struktura i układ materiałów w filmie}

Film Moja Misja stanowi kompozycję artystyczną o strukturze zamkniętej, wyraźnie zaznaczonym początku i zakończeniu. Materiały zostały ułożone chronologicznie $\mathrm{w}$ taki sposób, aby były zrozumiałe, nie wymagały dodatkowych wyjaśnień czy uzupełnień. Film M. Fajbusiewicza można pod względem treści określić jako biograficzny, więc wybór takiej właśnie struktury wydaje się oczywisty. Autorzy zaczynają opowieść od dzieciństwa i młodości profesora. Początek tej opowieści ma swoje źródło w Łodzi, gdzie Jan Karski urodził się jako Jan Kozielewski ${ }^{20}$ i mieszkał w ubogiej, rzemieślniczej rodzinie przy ul. Kilińskiego 107. Tutaj wychowywał się w atmosferze uwielbienia dla Józefa Piłsudskiego $\mathrm{i}$ - co ważne dla obecnych w filmie wątków wyznaniowych - w wierze katolickiej, jednak przy zachowaniu tolerancji dla innych wyznań. Wykształcenie wyższe zdobył na uniwersytecie we Lwowie, gdzie studiował prawo i dyplomację. Po studiach odbył służbę wojskową z wyróżnieniem, dostając stopień oficerski. Jeszcze w międzywojniu zainteresowało się nim Ministerstwo Spraw Zagranicznych II RP, wysyłając go na liczne szkolenia, stypendia i misje zagraniczne do krajów Europy Zachodniej (głównie Francji i Anglii). Ten fragment życiorysu profesora pokazany jest niezbyt obszernie, ale barwnie: autor filmu dotarł m.in. do dawnych kolegów gimnazjalnych J. Karskiego, którzy przed kamerą zaśpiewali mu fragment piosenki o piłsudczykach.

Jak wcześniej wspomniano, korzenie łódzkie pokazano we współczesnej filmowi Łodzi - uzupełniając jednak współczesne zdjęcia licznymi archiwaliami. Jeżdżono z profesorem w liczne miejsca związane z jego dzieciństwem i wczesną młodością, jak m.in. w miejsce, gdzie znajdowała się wówczas kamienica, w któ-

19 Wskazuje na to proporcja materiałów archiwalnych, występujących w przybliżeniu w stosunku 1/3 do współcześnie rejestrowanego materiału wideo. Zważywszy na możliwość zarejestrowania faktycznie nieco większej ilości nagrania niż czas podany przez producenta - jak również przypuszczenie, że nie wszystkie niedostępne już kasety musiały być zapisane całkowicie - podane tu proporcje należy traktować wyłącznie jako przybliżone.

${ }^{20}$ Kozielewski to prawdziwe nazwisko profesora; nazwisko Karski było pierwotnie jego pseudonimem konspiracyjnym, który po wojnie przyjął na stałe. 
rej mieszka1 ${ }^{21}$; „Zwiedzono” w ten sposób znaczną część centrum Łodzi, z ulicą Piotrkowską i placem Wolności na czele. W Warszawie ekipa nagrywała zdjęcia w kościele Świętego Krzyża, z którym J. Karski był związany w międzywojniu i później, w konspiracji. Zarejestrowano także spotkanie profesora z Żydami ocalałymi z Holocaustu na warszawskim Umschlagplatzu.

Z większą szczegółowością i bardziej obszernie opowiedziano w filmie działalność J. Karskiego podczas II wojny światowej: aresztowanie i osadzenie w obozie sowieckim w Kozielszczynie; wymianę ludności i ucieczkę z niemieckiego pociągu na terenie okupowanej przez hitlerowców Polski; zaciągnięcie się do konspiracji i pierwsze misje kurierskie; wpadkę na granicy ze Słowacją i osadzenie w gestapowskiej katowni w Preszowie, gdzie profesor podciął sobie żyły; zorganizowanie ucieczki ze szpitala w Nowym Sączu (dokąd przewiozło go gestapo) i wreszcie dalszą działalność w konspiracji. Punktem kulminacyjnym filmu jest jednak najważniejsza misja J. Karskiego: dotarcie do aliantów zachodnich z raportem i informacjami na temat losu Żydów w okupowanej Polsce. Celem organizacji żydowskich w kraju, z którymi skontaktował J. Karskiego Cyryl Ratajski, było przede wszystkim przesłanie do aliantów zachodnich następującego przekazu: oczekiwania, by „ratowanie Żydów od zagłady stało się częścią strategii wojennej aliantów”. Jak powszechnie wiadomo, na Zachodzie Karskiemu nie uwierzono. Przywódcy wojenni do samego końca II wojny światowej nie ujawniali stanu wiedzyi świadomości na temat tragedii Żydów w okupowanej Polsce, mimo że zostali profesjonalnie poinformowani; nie tylko przez obszerny, 34-stronicowy raport na mikrofilmie, który Karski na Zachód przemycił, ale także na podstawie osobistych obserwacji, jakich dokonał, wprowadzony przez organizacje żydowskie do getta warszawskiego oraz miejsc zagłady Żydów w Izbicy i Bełżcu. Temu tematowi - opisanemu szczegółowo i wzbogaconemu o wypowiedzi licznych osobistości i wiele materiałów archiwalnych - poświęcono 30 minut z 74-minutowej całości. Ponieważ jednak przez cały czas trwania filmu zachowano spójność kompozycyjną: podobne tempo montażu, sposób przeplatania „setkami”22 i archiwaliami - widz nie ma wrażenia spowolnienia akcji ani spadku napięcia dramatycznego. Należy jednak zwrócić uwagę na ten zabieg retoryczny, zastosowany na płaszczyźnie kompozycji, a polegający na zastosowaniu charakterystycznych proporcji czasowych w prezentowaniu opisywanych wydarzeń.

${ }^{21}$ W 1996 roku, gdy film realizowano, w pobliżu tego miejsca znajdował się dworzec Łódź Fabryczna w zabytkowej jeszcze wersji, a także nieistniejący już dziś hotel Centrum powstały w latach 70. XX w.; po drugiej stronie skrzyżowania z ulicą Narutowicza Filharmonia Łódzka z lewej strony oraz hotel Polonia z prawej. Obecnie hotel Centrum zburzono, podobnie jako dworzec Łódź Fabryczna, w miejsce którego zbudowano całkowicie nową infrastrukturę kolejową i inne budynki (Brama Miasta, Galeria EC-1), zaś teren całkowicie zrewitalizowano. Ma to znaczenie dla współczesnego widza, ponieważ pokazywana w tym filmie Łódź wygląda obecnie zupełnie inaczej.

22 Setka - wypowiedź do kamery cechująca się 100\% zgodnością obrazu z dwiękiem. 
Jako że misja Karskiego była bez wątpienia najważniejszym elementem treści filmu, zdecydowano się dokonać swoistej amplifikacji za pośrednictwem struktury, przy jednoczesnym zachowaniu dotychczasowej dynamiki na poziomie montażu (stąd nie możemy mówić jeszcze o hiperboli). Oczywiście wymagało to zebrania większej ilości informacji i szczegółów, a więc dokładniejszego przyjrzenia się temu fragmentowi życiorysu profesora; autorzy dokumentu musieli mieć tę świadomość już na poziomie inventio.

Dalsze sekwencje filmu są już poświęcone powojennemu życiu Jana Karskiego: jego karierze naukowej na Georgetown University w Waszyngtonie, zainteresowaniom naukowym (przede wszystkim politologicznym i historycznym) oraz związkowi małżeńskiemu z Polą Nireński, polską tancerką pochodzenia żydowskiego, którą poznał jeszcze przed 1939 rokiem. Wątki naukowe, w tym liczne nagrody i wyróżnienia, zostały skwitowane w filmie jedynie kilkoma zdaniami. J. Karski zastrzegł sobie, by ich nie eksponowano, ponieważ uważał je za „przeceniające jego postać oraz niezasłużone”, o czym autorzy poinformowali widza w napisach końcowych, zaprezentowanych na tle ostatniej sekwencji, nakręconej w Izraelu. Jednakże autorzy filmu o tych osiągnięciach wspomnieli. Inaczej sprawa kształtuje się z wątkami osobistymi. Kasety z materiałem surowym zawierają m.in. zdjęcia Jana Karskiego na cmentarzu w Jerozolimie, gdzie odwiedza on grób swoich teściów (jako jedynych ocalałych z rodziny jego żony, dzięki ucieczce przed wojną). Sekwencje te nie zostały w filmie wykorzystane. Mamy tu więc do czynienia ze świadomym współkształtowaniem dokumentu przez jego bohatera na płaszczyźnie dispositio. Jan Karski niejednokrotnie prosił, by określone treści były lub nie były eksponowane albo by w ogóle nie były poruszane.

Śmierć żony J. Karskiego została opowiedziana w filmie także w dyskretny sposób: profesor opowiada jedynie o dniu jej pogrzebu i pokazuje nagrobek na cmentarzu w Waszyngtonie, na którym widniało także jego nazwisko bez daty śmierci (został tam pochowany w lipcu 2000 roku). Nie wspomina się jednak o fakcie, że żona J. Karskiego cierpiała na depresję i zmarła w wyniku szóstej już próby samobójczej, skacząc z balkonu mieszkania na 11. piętrze. Te szczegóły M. Fajbusiewicz zdecydował się ujawnić dopiero po wielu latach w wywiadzie-rzece (Fajbusiewicz, Omilianowicz 2019: 242). Ten i inne przykłady świadczą z kolei o tym, jak dużą wagę autor dokumentu przywiązywał do kwestii etycznych - i jak wielkie znaczenie miały one dla niego na etapie dispositio w przygotowywanych przez siebie filmach ${ }^{23}$. Obce mu były mechanizmy tabloidyzacji, która zaczynała wówczas pojawiać się w polskich przekazach medialnych ${ }^{24}$.

23 Potwierdzić to można na przykładzie innych filmów dokumentalnych Michała Fajbusiewicza oraz - przede wszystkim - jego sztandarowego magazynu kryminalnego 997, który jest przedmiotem zainteresowań badawczych autora analizy.

${ }^{24}$ W filmie nie eksponowano również postaci brata Karskiego, Mariana Kozielewskiego - dzięki którego opiece i pozycji w dyplomacji profesor zawdzięczał swą dalszą 
Ostatnia sekwencja tematyczna stanowi swoistą klamrę kompozycyjną filmu. Są to zdjęcia nakręcane w Izraelu: w Jerozolimie, na Górze Masada, w Betlejem w Bazylice Narodzenia Pańskiego, wreszcie w Alei Sprawiedliwych wśród Narodów Świata z Instytucie Yad Vashem oraz w Dolinie Zabitych Wspólnot (nagraniem z tego miejsca zakończono film). Sekwencję tę, bardzo krótką, ale symboliczną, uzupełniono zdjęciami z cmentarza żydowskiego w Łodzi. Podobnie jak na warszawskim Umschlagplatzu i tu spotyka Jana Karskiego Żydówka, której rodzice zmarli z głodu w getcie łódzkim. Tworzy się specyficzny kontrast między cynizmem polityków Zachodu a ocalałymi przedstawicielami prześladowanej społeczności żydowskiej. Jest to argument typu aksjologicznego, wartościującego. Zdjęcia te - jakkolwiek merytorycznie jednoznaczne i oczywiste - grają jednak rolę arystotelesowskiego pathos, wpływając na emocje widza i umożliwiając jego katharsis. Bez wątpienia te ostatnie fragmenty filmu, trwające lącznie 7 minut, są najbardziej wzruszające na tle całości i mają katarktyczny charakter. W warstwie werbalnej zaś wyrażają sens misji Jana Karskiego, sens jego życia - i tym samym dokumentu telewizyjnego. Sens ten telewidz odnajdzie w trzech wypowiedziach profesora:

Żydzi byli wtedy w czasie wojny bezbronni. Niewyobrażalnie słabi. Nie mieli własnego państwa. Nie mieli własnego rządu. Nie mieli własnych umundurowanych armii. Zdani byli na dobrą wolę innych. I pamiętajmy też: Żydzi byli wtedy opuszczeni przez istniejące rządy, przez istniejące struktury społeczne, przez hierarchię kościelną. Ale nie byli opuszczeni przez całą ludzkość. I o tym Żydzi powinni też pamiętać - i pamiętają.

(na Górze Masada, Izrael)

Ja - Jan Karski, z urodzenia Jan Kozielewski, katolik, Polak, Amerykanin - stałem się teraz także Izraelczykiem. Gloria, gloria in Excelsis Deo!

(Aleja Sprawiedliwych wśród Narodów Świata, Instytut Yad Vashem - przy tabliczce i drzewie Jana Karskiego)

Tutaj urodził się zbawiciel, w świecie żydowskim. Poprzez tysiące lat tradycja żydowska mówiła, że Żydzi są narodem wybranym. Jak nas uczył Kościół nasz, Żydzi są narodem wybranym dla także nas, chrześcijan, ponieważ poprzez Żydów Bóg się nam objawit. Tutaj przychodzą dzień po dniu pielgrzymki z całego świata. Pielgrzymki chrześcijan i innych wyznań. Tu oddajemy nasz hołd i naszą wiarę Zbawicielowi.

(Bazylika Narodzenia Pańskiego, Betlejem)

Umieszczenie tych właśnie zdjęć i wypowiedzi bohatera na końcu filmu ma swoje wyraźne uzasadnienie:

karierę. Wzmianki o nim czytelnik znajdzie we wspomnianym już wywiadzie-rzece (Fajbusiewicz, Omilianowicz 2019). 
- uwypukla ich patetyczny i katarktyczny charakter;

- puentuje cały film, którego podstawowym sensem jest objaśnienie widzowi związanej z Holokaustem misji Karskiego i jej znaczenia;

- spaja i syntetyzuje moralny przekaz, jakim jest pokazanie na przykładzie Holokaustu ludzkiego okrucieństwa i moralny obowiązek przeciwstawienia się temu okrucieństwu;

- skupia uwagę widza na tym moralnym przesłaniu, każąc mu je zapamiętać - z największym bowiem napięciem widz wyczekuje zakończenia filmu i ono też zostaje na ogół najlepiej zapamiętane.

Takie zakończenie filmu jest więc świadomie stosowaną strategią argumentacyjną, mającą przekonać telewidza o ważności i doniosłości prezentowanych w filmie treści. Było ono jednak motywowane także emocjami i uczuciami autora. Podczas jednego ze spotkań z publicznością Michał Fajbusiewicz - mający żydowskie korzenie - wyznał, że wizyta w Izraelu, Instytucie Yad Vashem i Dolinie Zabitych Wspólnot była dla niego bardzo dużym przeżyciem ${ }^{25}$. Finałowe sekwencje filmu są więc nie tylko symboliczne, ale także bardzo osobiste. Znajduje to jeszcze potwierdzenie w częstej obecności tematyki żydowskiej w twórczości dokumentalnej tego dziennikarza.

\subsubsection{Elocutio - analiza środków wyrażania w filmie}

Cechy kompozycyjne i stylistyczne filmu Michała Fajbusiewicza przesądzają o jego artystycznym charakterze. Zarówno pod względem układu treści i struktury (dispositio), jak również efektów audiowizualnych (tu traktowanych jako swoiste zabiegi stylistyczne - na poziomie elocutio) sprawiają, że zasadniczo różni się on od innych produkcji tamtego czasu, poświęcanych sprawom bieżącym: społecznym, politycznym, kryminalnym czy jakimkolwiek innym. O jego indywidualnym, elokucyjnym charakterze świadczyć będzie sposób dokonywania zdjęć i ich montażu, oprawa muzyczna, napisy i infografika (jak np. krój czcionki), wykorzystywane w produkcji obrazy i dźwięki o charakterze bardziej estetycznym niż merytorycznym (np. informującym widza o czymś lub pozwalającym mu zrozumieć czy unaocznić jakieś treści).

Analizując programy telewizyjne, a reportaże i filmy dokumentalne w szczególności, trzeba mieć jednak świadomość czasu oraz dostępnych technologii, w jakich powstawały. Sam autor wyraził przekonanie, że dziś - z perspektywy upływu niemal ćwierć wieku od realizacji swojego dokumentu - zrealizowałby go już inaczej pod względem stylistycznym. Niemniej, funkcjonując w dziennikarstwie telewizyjnym w Polsce - także w okresie lat 90. - i pracując dla Telewizji

25 Te odczucia Michał Fajbusiewicz wyraził na spotkaniu ze studentami Dziennikarstwa i Komunikacji Społecznej Uniwersytetu Łódzkiego, zorganizowanego przez autora tekstu na 7.04.2017. 
Polskiej (w owym czasie rynek stacji komercyjnych dopiero zaczął się rozwijać), siłą rzeczy podlegał licznym ograniczeniom. Najważniejszym z nich był budżet - skalę jego różnicy można było uchwycić, porównując chociażby pieniądze przeznaczone na realizację jednego odcinka $997 \mathrm{w}$ stosunku do niemieckiego odpowiednika X Y - Akta Niewykrytych Spraw (byly to proporcje rzędu kilkuset tysięcy marek do kilkudziesięciu tysięcy złotych). Drugim - nie mniej ważnym - była technologia, w jakiej Telewizja Polska w Łodzi wówczas pracowała. Wszystkie niemal programy produkowane były w technice analogowej, rejestrowane kamerami i magnetowidami na kasetach systemu Betacam SP. Ta technika zapisu - jakkolwiek profesjonalna - była jednak analogowa, więc praca z nią była znacznie trudniejsza i bardziej czasochłonna niż z jakimkolwiek formatem cyfrowym, a możliwości obróbki i montażu obrazu - ograniczone. Stąd też wynika pewna „surowość” użytych środków formalnych, do której współczesny telewidz nie jest przyzwyczajony. Michał Fajbusiewicz zaś - związany z telewizją od 1982 roku - swoje pierwsze reportaże realizował z ekipą telewizyjną na taśmie celuloidowej, w warunkach jeszcze trudniejszych niż opisane. Nie ma więc wątpliwości, że wraz ze swoimi współpracownikami natychmiast docenił technologię Betacam i wykorzystał maksymalnie jej możliwości.

Pierwszą kwestią istotną z punktu widzenia elocutio jest podmiot mówiący - odpowiedź na pytanie, kto i do kogo się wypowiada. Pojęcie to rozumieć należy nieco szerzej niż podmiot retoryczny. Nie zawsze bowiem ów podmiot musi materializować się w postaci konkretnej osoby występującej na ekranie. W programach informacyjnych, zwłaszcza magazynach wiadomości, owym podmiotem jest zazwyczaj prowadzący program anchorman, zaś w relacji lub sprawozdaniu reporterskim - przygotowujący je dziennikarz. To jego głos telewidz słyszy, jego postać widzi niekiedy podczas stand-upu na końcu materiału (chociaż coraz częściej odstępuje się od tego ze względu na ekonomiczność przekazu), zna go też z imienia i nazwiska. W przypadku filmu dokumentalnego nie jest to już oczywiste. Niekiedy owym „ja mówiącym” jest tu bohater lub bohaterowie, czasem jest to lektor (czytający jednak tekst przygotowany przez kogoś innego, choć mogący mieć duży wpływ na interpretację tekstu ${ }^{26}$ ), a niekiedy sam autor filmu ujawnia swoją obecność, mówiąc do widza, wprowadzając go w świat swojego filmu dokumentalnego, nierzadko odsłaniając kulisy swojej pracy. Są to typowe cechy gatunkowe, wyróżniające film dokumentalny od innych gatunków telewizyjnych. Do takich filmów należą choćby: Wtadcy marionetek (reż. Tomasz Sekielski), Szpieg (reż. Bogdan Rymanowski, Wojciech Bockenheim - widz ogląda tego pierwszego, tworzącego z Marianem Zacharskim swoisty „podmiot zbiorowy”). Dokumenty takie tworzył również często Michał Fajbusiewicz - występując w nich nie tylko w roli reportera,

${ }^{26}$ Wynika to z doświadczeń autora analizy, który jest prezenterem, lektorem w reklamach i przekazach medialnych oraz lektorem audiobooków. 
ale także i swoistego przewodnika (np. w swoich filmach i reportażach podróżniczych); często także sam czytał napisane przez siebie lektoraty.

Film Moja Misja jest dokumentem telewizyjnym, który opiera się na opowieści głównego bohatera, Jana Karskiego. Stąd też na ekranie częsta obecność profesora, bądź to w postaci setek, bądź przebitek i ujęć reżyserowanych, a niekiedy - głosu z offu, przykrytego zdjęciami archiwalnymi bądź zdjęciami plenerów. Profesor jest więc głównym "ja mówiącym” w filmie (choć nie jedynym). Można przeto spojrzeć na jego postać jak na podmiot retoryczny: „osobę mówcy, obdarzoną całokształtem cech, mogących wpływać na jego zdolności przemawiania, a tym samym perswadowania (lub nawet manipulowania). Pojęcie to można rozpatrywać w kategoriach antropologii, ale także podmiotowości, a przede wszystkim - osobowości" (Grzegorzewski 2014: 25). Wśród cech tych notuje się: pochodzenie i wychowanie (także w sensie czasów, z jakich się pochodzi), wiek i doświadczenie, wykształcenie, środowisko społeczne, środowisko polityczne i zawodowe, cechy charakteru, sprawność i kreatywność retoryczna, dorobek twórczy (Grzegorzewski 2014: 32-44). Dla dopełnienia analizy można jeszcze zestaw cech osobowościowych uzupełnić o doświadczenia osobiste. Osobną kategorią są cechy wyglądu zewnętrznego, brzmienie głosu i prozodia, zachowania niewerbalne (mimika i gesty). Analiza taka zajęłaby zbyt wiele miejsca i wymagałaby czasochłonnych badań, czyli musiałaby być przedmiotem osobnego i bardziej obszernego opracowania. Gdyby jednak chcieć dokonać takich badań w filmie dokumentalnym Moja Misja, dotyczyłyby one właśnie Jana Karskiego jako homo rhetoricusa.

Drugim „ja mówiącym” w filmie jest lektor Tomasz Boruszczak, czytający tekst zredagowany przez Michała Fajbusiewicza i Waldemara Piaseckiego. Sami autorzy dokumentu pozostają ukryci: widz nie dostrzega ich ani razu w kadrze, nie słyszy ich głosów, nie widzi ich w działaniu. Ich obecność zdradzają jedynie robocze kasety, na których słychać co jakiś czas ich pytania bądź prośby kierowane do profesora ${ }^{27}$ lub innych rozmówców. Słychać też niekiedy wymianę zdań między red. Fajbusiewiczem a członkami ekipy; ma ona charakter warsztatowy i wiele ciekawego może powiedzieć o kulisach pracy dziennikarskiej. Telewidz jednak nie ma dostępu do takich materiałów i może się zorientować dopiero z napisów końcowych, kto jest autorem dokumentu.

Wypowiedzi innych osób, jak wspomniano, są przywoływane w wymiarze kilku zdań - poprzedzanych zawsze kadrem danej osoby ujętej w lekko zakrzywioną, trapezowatą ramkę i podpisem imienia, nazwiska i funkcji pod spodem. Bo blisko dwusekundowej stopklatce postać jest wykadrowana $\mathrm{z}$ trapezu do wymiaru pełnego ekranu i zaczyna mówić. Dziś efekt ten uchodzić może za nienaturalny - ale paradoksalnie ułatwia on zapamiętanie, kto się wypowiada. Wy-

27 Ciekawym przykładem jest prośba operatora Adama Kaczanowskiego do prof. Karskiego: „Niech pan profesor się przespaceruje, a ja będę go sobie jak mrówkę oglądał!”. 
powiedzi te stanowią uzupełnienie wobec narracji prowadzonej przez bohatera i autorów filmu. $Z$ punktu widzenia sztuki argumentacji należy je uznać przede wszystkim za argument $\mathbf{z}$ autorytetu - $\mathrm{w}$ dużej mierze dotyczą bowiem oceny osoby i działalności Jana Karskiego, a wygłaszają je osoby istotnie będące autorytetami, choćby z racji pełnionych przez siebie funkcji.

Moja Misja jest filmem bardzo atrakcyjnym od strony przekazu wizualnego. Ze względu na historyczną tematykę, ale także dostęp do dużej ilości materiałów archiwalnych, jest on bardzo bogato ilustrowany archiwalnymi fotografiami (konkretnych postaci, plenerów, dokumentów bądź form artystycznych, jak np. obrazy, grafiki, rzeźby, pomniki i wiele innych). Pojawiają się także kadry starych, zachowanych filmów archiwalnych, głównie z okresu II wojny światowej: walki artylerii, czołgów, lotnictwa, a także wstrząsające fotografie i filmy z getta lódzkiego, getta warszawskiego, obozów koncentracyjnych. Wykorzystanie archiwaliów w filmie pełni funkcję nie tylko informacyjną, ale także perswazyjną, oddziałując na uczucia widza. Zdjęcia mogą budzić uśmiech, nostalgię, wzruszenie (pierwsze sekwencje filmu), grozę, wstrząs i przerażenie, oburzenie, wreszcie żal, smutek - zwłaszcza wtedy, gdy jest mowa o okrucieństwach wojny i Holokaustu. Te ujęcia zwykle nie są długie - najwyżej kilkunasto-, dwudziestosekundowe. Montażysta często nakłada je na siebie, stosując efekt przenikania, powolnie rozciągniętego $\mathrm{w}$ czasie; innym razem przeplata je z przejeżdżającymi po torach wagonami bydlęcymi, filmowanymi często z boku i u dołu (pokazującymi głównie podwozia i koła). Motyw przejeżdżających wagonów pojawia się w filmie regularnie, zwłaszcza w sekwencjach opisujących wojenne misje J. Karskiego. Przez szereg skojarzeń z innymi, podobnymi filmami o tematyce obozowej, tory i wagony bydlęce nieodmiennie przywodzą na myśl obozy koncentracyjne i komory gazowe. Można więc mówić tu o tropie retorycznym zwanym pars pro toto (transportowanie wagonami bydlęcymi w nieludzkich warunkach do obozów jest częścią systemu eksterminacji, zarówno w systemie nazistowskim, jak i sowieckim). Jest on sygnalizowany już na początku, przez ujęcie bardzo wolno przesuwającego się na ekranie zarośniętego toru kolejowego - zarośnięcie i zaniedbanie również niesie za sobą określony ładunek symboliczny (przemijanie, śmierć, zapomnienie). Elektroniczne spowolnienie ruchów kamery przydaje ujęciom złowróżbnego, ponurego charakteru.

Podobne przenikanie się zdjęć wojennych i współczesnych (skądinąd jest to częsty chwyt w filmach historycznych) zastosowano, opowiadając o sytuacji w okupowanej Warszawie. Innym zabiegiem stylistycznym, sprzyjającym wzrostowi napięcia dramatycznego, jest przekontrastowienie zdjęć, manipulacja balansem bieli (wyglądają one jak prześwietlone, są nienaturalne), a nawet manipulacja nasyceniem barwnym (chroma) ${ }^{28}$. Podobne chwyty będące hiperbolą

28 Takie możliwości zapewnia już sam magnetowid, bez konieczności użycia efektów stołu montażowego. 
zastosowano, np. pokazując zdjęcia lasu na granicy, przez którą przedostał się Jan Karski na Słowację, gdzie w końcu wpadł w ręce gestapo. Stopniowaniu napięcia, a także budowaniu atmosfery grozy (rzadziej smutku, melancholii) towarzyszy manipulowanie czasem wyświetlania sekwencji. $\mathrm{W}$ analizowanym filmie wiele zdjęć przedstawiono w zwolnionym tempie. Efekt ten potęgują czasem nierówne, chwiejne ujęcia kamery.

Twórcy filmu starannie unikali ujęć dłuższych niż kilka lub kilkanaście sekund, podobnie jak ujęć statycznych. Kamera zazwyczaj była w ruchu: podążała w ślad za profesorem, „wchodziła” wraz z widzem i operatorem po schodach starej kamienicy, przesuwała się nieco nierówno, pozornie niestarannie filmując postaci, plenery, obiekty. W odniesieniu do tekstu werbalnego odpowiednikiem takich działań elokucyjnych byłyby zabiegi składniowe stosowane w celu dynamizowania tekstu: przewaga krótkich zdań nad długimi, strony czynnej nad bierną, czasownikami nad rzeczownikami i przymiotnikami, unikanie konstrukcji imiesłowowych etc. W celach perswazyjnych unikano także nadmiaru statycznych ujęć osób mówiących. Poza wypowiedziami profesora (inne osoby zaś mówiły w filmie niewiele, po kilka zdań) najważniejsze było pokazywanie go $\mathrm{w}$ akcji, $\mathrm{w}$ plenerach, $\mathrm{w}$ ruchu, niekiedy przy prozaicznych czynnościach: spacer po ulicy, cmentarzu, wzdłuż murów; przyklękanie przy ołtarzu kościoła bądź w Bazylice Narodzenia Pańskiego, przysiadanie na ławkach bądź innych obiektach w miejscach ważnych z punktu widzenia narracji. Jan Karski - podówczas człowiek ponad osiemdziesięcioletni, schorowany - poruszał się powoli, niepewnie, charakterystycznym sztywnym krokiem. Siadanie bądź klękanie w obiektach sakralnych sprawiało mu wiele kłopotu. Poruszanie się z wyraźnym trudem, zmęczenie, niekiedy grymas bólu na twarzy profesora - mogą wywoływać wzruszenie, a nawet żal. Fajbusiewicz wspomina, że odbył z profesorem i swoją ekipą wiele podróży, liczne przeloty i przejazdy, wędrówki po wielu miejscach, których wymagała realizacja filmu. Profesor nigdy nie zdejmował marynarki, był zawsze w garniturze, niezależnie od upału. Ze względu na stan zdrowia i częstą fizyczną niedyspozycję nie udawało się go namówić na niektóre ujęcia; z tego też powodu niekiedy przerywano zdjęcia, przekładając je na dzień następny. Na kasetach roboczych profesor niekiedy skarżył się na zmęczenie lub ból kolana. Z godną podziwu cierpliwością jednak stosował się do próśb operatora o powtórzenie jakiejś sceny, pochylone przejście przez bardzo niskie drzwi (np. bazyliki w Betlejem; tego zdjęcia nie wykorzystano), pokonanie jeszcze jednego odcinka drogi, kolejne powtórzenie tej samej kwestii. Cytowaną wyżej wypowiedź z Alei w Yad Vashem Jan Karski powtarzał trzykrotnie. Realizatorzy dokumentu wybrali wersję najbardziej dobitnie i patetycznie brzmiącą - z punktu widzenia kompozycji bez wątpienia trafnie. Wysiłki profesora Karskiego, jego poświęcenie, doskonale widoczne w obrazie telewizyjnym, budzą podziw i szacunek widza. Nie należy oczywiście zakładać, że autorzy filmu ów efekt chcieli osiągnąć celowo; niemniej obserwowane na ekranie zachowania profesora same przez się pełnią 
bardzo istotną funkcję w szeroko pojętej argumentacji: przekonują do niego widza, nakazują widzowi traktować tę postać ze wzruszeniem, powagą i szacunkiem (oddziaływanie emocjonalne).

Tę skrótową z konieczności analizę filmu wypada zamknąć kilkoma uwagami na temat warstwy audialnej. W swej bogatej twórczości telewizyjnej Michał Fajbusiewicz niejednokrotnie korzystał z pomocy lektorów, zatrudnionych $\mathrm{w}$ lódzkim oddziale Telewizji Polskiej. Wśród najbardziej znanych można wymienić Zbigniewa Zalińskiego, Wojciecha Barczaka, ale także Dariusza Mazurka, Andrzeja Królikowskiego czy - sporadycznie - Grażynę Jeżewską. Niekiedy ścieżki lektorskie nagrywał sam. Od 1993 roku zaczął współpracować także z Tomaszem Boruszczakiem: prezenterem i dziennikarzem telewizyjnym, scenarzystą, aktorem teatralnym, a nawet wokalistą (swego czasu wykonującym muzykę metalową). Przez ponad dekadę T. Boruszczak czytał lektoraty w większości reportaży i filmów M. Fajbusiewicza. Dysponuje on głębokim, niskim głosem (jest to bas) o barwie ostrej i wyrazistej, stosunkowo dużej rozpiętości intonacyjnej, ale przy tym melodyjnym i cechującym się bardzo czystą, selektywnie brzmiącą dykcją. Uznanie dla zdolności lektorskich T. Boruszczaka jest powszechne: między innymi, w pierwszej i drugiej dekadzie XXI wieku wykorzystywano zarejestrowane jego głosem w Łodzi nazwy przystanków i linii komunikacji miejskiej, odtwarzane później w łódzkich autobusach i tramwajach ${ }^{29}$. Głos ten został właśnie wykorzystany w filmie Moja Misja - lektor przeczytal tekst starannie, tempem umiarkowanym (określanym muzycznym terminem moderato), przy użyciu niskiej tonacji i umiarkowanej melodii głosu - spokojnie, starannie i selektywnie. Taki sposób interpretacji tekstu przydaje dokumentowi poważnego charakteru, zaś opisywanym wydarzeniom - szczególnie dużej wagi. Wpisuje się to w oddziaływanie typu emocjonalnego (pathos).

Brakuje niestety informacji o wykorzystanych w filmie utworach muzycznych; Telewizja Polska w Łodzi nie podawała zazwyczaj informacji o muzyce wykorzystywanej w swoich produkcjach. Dotyczyło to także reportaży, filmów dokumentalnych i programów cyklicznych M. Fajbusiewicza. Wiadomo jedynie, że za oprawę muzyczną tego filmu (jak i wielu innych produkowanych przez TVP Łódź) odpowiada Jolanta Grzybowska. W swej wieloletniej współpracy autor korzystał, poza wsparciem J. Grzybowskiej, jeszcze z pomocy Iwony Kawiorskiej i Ryszarda Gibkiego. Po 1995 roku dało się zauważyć wyraźną zmianę trendów w oprawie muzycznej Telewizji Polskiej w Łodzi; po ustawowym uregulowaniu kwestii praw autorskich przestano korzystać z dostępnej komercyjnie muzyki poważnej i rozrywkowej (najczęściej podówczas dostępnej niestety głównie zagranicą), a zaczęto stosować muzykę ze specjalnie do tego celu przygotowywanych

${ }^{29}$ W 2017 roku głos T. Boruszczaka w tramwajach i autobusach został zastąpiony głosem Tomasza Zimocha - znanego dziennikarza i komentatora sportowego. 
bibliotek muzycznych ${ }^{30}$. Można więc jedynie scharakteryzować ją od strony brzmienia i gatunku.

W tym filmie dominują aranżacje na kameralne zespoły muzyczne, przede wszystkim smyczki - ze szczególnym uwzględnieniem skrzypiec. Trzeba jednak przyznać, że muzyka jest dobrana różnorodnie. W jednej z początkowych sekwencji daje się uchwycić muzykę mechaniczną (elektroniczną) pochodzącą z tej samej biblioteki muzycznej, której J. Grzybowska używała także do ilustrowania programu 997 - jest to jednak wyjątek ${ }^{31}$. Autorka oprawy muzycznej sięga do muzyki w skali dur-mol ( $w$ tonacji molowej), korzysta $\mathrm{z}$ utworów atonalnych, dobiera style i brzmienia do treści filmu, uruchamiając stosowne skojarzenia w muzycznej wyobraźni widza. W sekwencji, gdzie zaprezentowano zagadnienie mniejszości żydowskiej w międzywojniu (w tym sytuacji żydowskich studentów na uniwersytetach), pojawia się muzyka na skrzypce solo z akompaniamentem gitary. Wywołuje tym wyraźne skojarzenia z żydowską kulturą muzyczną (w której bardzo często występują utwory na skrzypce solo z akompaniamentem), ale rytmiczność gitary nie zwiastuje jeszcze niczego niepokojącego ani tym bardziej okrutnego. Jednak przy opisie przekraczania granicy polsko-słowackiej i wpadki J. Karskiego pojawia się muzyka atonalna, przywodząca na myśl pełną dramatyzmu współczesną muzykę poważną (co ma wywołać uczucie niepokoju, zagrożenia zbliżającą się katastrofą). Co najmniej dwóm scenom o charakterze „konspiracyjnym” towarzyszy budująca napięcie minimalistyczna sekwencja zagrana na gitarze basowej, $\mathrm{z}$ towarzyszącym dodatkowym motywem. Bardzo wymowne są także fragmenty wykorzystane w ostatnich sekwencjach filmu, w tym zdjęciach realizowanej w Dolinie Zabitych Wspólnot. Ostatni utwór został lekko zniekształcony przy pomocy charakterystycznego efektu „studni” - przypominającego nieco pracę elektronicznej kamery pogłosowej. Być może jest to efekt monofonizacji utworu pierwotnie stereofonicznego (wszystkie produkcje TVP Łódź były w tamtym czasie monofoniczne - a i widzowie na ogół nie mieli telewizorów stereofonicznych). Potęguje on przygnębienie i grozę, jaką budzi zwiedzanie wraz z profesorem Doliny Zabitych Wspólnot w Yad Vashem. Charakterystyczne chóralne śpiewy męskie i wreszcie melancholijny chóralno-smyczkowy motyw w ostatniej scenie budzą smutek - ale także refleksję. Sprzyjają one wspomnianej wcześniej funkcji katarktycznej - podobnie jak przez obraz i wymowę ostatnich w filmie słów profesora, także i tu realizatorzy filmu pragnęli osiągnąć głębokie wzruszenie widza, refleksję - wyperswadowując mu płynące z filmu przesłanie moralne.

${ }^{30}$ Dostęp do bibliotek muzycznych Czytelnik znajdzie na stronie APM Music. Muzykę można wyszukiwać według wytwórni, wykonawcy, tytułu, gatunku muzycznego, a nawet zastosowania do sekwencji o określonej treści lub charakterze (np. agressive, furious, nervous, calm, melancholy lub: sensation, science fiction, technical, metallic etc.). Zob. http://apmmusic.com [dostęp: 27.07.2020].

${ }^{31}$ Chodzi tu m.in. o wytwórnię Kosinus Music oraz Koka i APM. 
Konstatujemy więc, że ilustracja muzyczna w filmie jest nie tylko interesująca i bogata pod względem artystycznym. Jest ona także nader trafna w sensie argumentacyjnym, perswazyjnym - a więc także retorycznym. Wykorzystana w filmie Moja Misja muzyka brzmi przekonująco - pozostając zawsze adekwatną wobec treści i funkcjonalną w stosunku do przekazu retorycznego tego filmu.

\subsubsection{Zakończenie}

Jak wykazano, Moja Misja w reżyserii Michała Fajbusiewicza i Waldemara Piaseckiego spełnia wymogi gatunkowe filmu dokumentalnego: stanowi strukturę zamkniętą, która dokumentuje fragment rzeczywistości, tu: biografię Jana Karskiego i jego rolę w historii II wojny światowej oraz powojennej historii świata. W filmie tym nie dostrzega się obecności reportera - obaj jego reżyserzy pozostają ukryci za kamerą, nie grają żadnej roli, co upodabniałoby go do reportażu. Jak wcześniej wspomniano, film został również formalnie zaksięgowany jako dokumentalny, co wiązało się ze znacznie większym niż w przypadku reportaży budżetem oraz większymi wynagrodzeniami dla twórców i koniecznością płacenia tantiem za każdą emisję. Film zawiera typowe dla swojego gatunku elementy, takie jak: narracja lektora, wypowiedzi głównego bohatera, wypowiedzi osób związanych $\mathrm{z}$ tym bohaterem lub $\mathrm{z}$ wydarzeniami dotyczącymi treści filmu, relacje $\mathrm{z}$ wydarzeń historycznych, zdjęcia filmowe pochodzące z rzeczywistych miejsc związanych z jego treścią, liczne materiały archiwalne. Wszystkie te elementy występują prymarnie $\mathrm{w}$ funkcji dokumentowania opowiadanej w filmie rzeczywistości, ale pełnią także - jak wykazano to wyżej - ważną funkcję perswazyjną. Film nie zawiera zdjęć inscenizowanych ( $w$ tym: retrospektywnych, jak np. było to w przypadku przywoływanego serialu Szpieg) oraz elementów fikcji fabularnej. Wszystkie przedstawione $\mathrm{w}$ filmie zdarzenia i informacje są prawdziwe i potwierdzone $\mathrm{w}$ dokumentach, relacjach świadków historii i publikacjach. W filmie nie ma hipotez oraz komentarzy i dyskusji o charakterze publicystycznym.

Analiza kompozycji przeprowadzona w trzech etapach - inventio, dispositio, elocutio - dowodzi, że autorzy filmu wykonali wszystkie niezbędne prace, by film stanowił zamkniętą, dopracowaną i możliwie pełną pod względem informacyjnym formę filmową. Ponadto zastosowali szereg chwytów retorycznych - przede wszystkim na poziomie struktury filmu, przekazu wizualnego i audialnego - w celach perswazyjnego oddziaływania na widza. Przydają one filmowi atrakcyjności, ale mają także charakter funkcjonalny: pomagają przybliżyć widzom sylwetkę Jana Karskiego, uwypuklają znaczenie jego historycznej misji, podkreślają znaczenie i doniosłość poruszanej problematyki II wojny światowej, a w szczególności zagadnienia Holokaustu. Pozwalają ponadto przeżyć opowiadaną w filmie historię za pomocą wskazanych wyżej zabiegów retorycznych odwołujących się do emocji odbiorcy (pathos). Stosowanie takich chwytów świadczy o artystycznym charakterze filmu. 
Moja Misja jest filmem, który do dziś się broni - nie tylko dzięki swojej unikalnej wartości historycznej. Bez wątpienia zalicza się do kanonu polskich dokumentów historycznych i biograficznych. M. Fajbusiewicz był pierwszym dziennikarzem, który uświadomił widzom polskiej telewizji istnienie Jana Karskiego, wielkość tej postaci i jej doniosłą rolę w historii Polski, dokonując jej przełożenia z języka podręczników i historycznych monografii na język dziennikarstwa telewizyjnego. Dopomaga w tym retoryczność tego filmu - znakomicie skomponowanego przez autorów i ekipę Telewizji Polskiej w Łodzi.

Wkład tego i innych dokumentów Michała Fajbusiewicza w popularyzację polskiej historii (w tym tematyki żydowskiej) jest niewątpliwy. Sam autor także skorzystał na realizacji swego filmu, stał się on bowiem ważną inspiracją dla dalszej jego twórczości dokumentalnej i reportażowej. Twórczość ta - różnorodna, bogata artystycznie i tematycznie, a niestety wciąż nieopracowana naukowo i zupełnie niesłusznie niedoceniana - czeka na nowe odkrycie.

\section{Literatura}

Adams Sally, Hicks Wynford (2007), Wywiad dziennikarski, Wydawnictwo Uniwersytetu Jagiellońskiego, Kraków.

Fajbusiewicz Michał, Omilianowicz Magda (2019), Fajbus. 997 przypadków z życia, Kompania Mediowa, Warszawa.

Foss Sonja K. (2004), Rhetorical Criticism: Exploration and Practice, Prospects Heightss, Illinois.

Godzic Wiesław (2004), Telewizja i jej gatunki. Po Wielkim Bracie, Universitas, Kraków.

Godzic Wiesław, Kozieł Andrzej, Szylko-Kwas Joanna (2015), Gatunki i formaty we wspótczesnych mediach, Poltext, Warszawa.

Grzegorzewski Krzysztof (2014), Homo rhetoricus w telewizyjnym dziennikarstwie politycznym (programy z lat 2005-2007), Wydawnictwo Uniwersytetu Łódzkiego, Łódź.

Historia polityczna świata XX wieku (2004), red. M. Bankowicz, Wydawnictwo Uniwersytetu Jagiellońskiego, Kraków.

Karski Jan (2014), Tajne państwo: opowieść o polskim podziemiu, przel. G. Siwek, Znak Horyzont, Kraków.

Kwintylian (2002), Kształcenie mówcy, przeł. M. Brożek, Wydawnictwo Akademickie Żak, Warszawa.

Lichański Jakub Z. (2010), Retoryka a/i media. Próba określenia pól wspólnych, [w:] Styl - dyskurs - media, red. B. Bogolębska, M. Worsowicz, Wydawnictwo Uniwersytetu Łódzkiego, Łódź, s. 383-395.

Piasecki Waldemar (2015, 2017), Jan Karski. Jedno życie. Kompletna opowieść, t. 1-2, Wydawnictwo Insignis, Kraków.

Pisarek Walery (2002), Nowa retoryka dziennikarska, Universitas, Kraków 2002.

Przylipiak Mirosław (2006), Poetyka kina dokumentalnego, Wydawnictwo Uniwersytetu Gdańskiego, Gdańsk. 
Rees Laurence (2018), Holocaust. Nowa historia, przeł. Ł. Praski, Prószyński i S-ka, Warszawa.

Skarżyńska Krystyna (2011), Język reportażu telewizyjnego, Semper, Warszawa.

Sowa Andrzej Leon (2011), Historia polityczna Polski 1944-1991, Wydawnictwo Literackie, Kraków.

Szwajkowska Anita (2013), Wstęp do prozodii komunikacyjnej, [w:] Rozmowy o komunikacji 6. Dynamika dyskursu społecznego, red. G. Habrajska, Primum Verbum, Łódź, s. 117-166.

Uszyński Jerzy (2004), Telewizyjny pejzaż genologiczny, Telewizja Polska S.A., Warszawa. Wieczorkiewicz Paweł (2014), Historia polityczna Polski 1935-1945, Zysk i S-ka, Poznań.

http://apmmusic.com [dostęp: 27.07.2020]. 